\title{
Analysis of mugwort (Artemisia) pollen seasons in selected cities in Poland in 2018
}

Elżbieta Weryszko-Chmielewska', Krystyna Piotrowska-Weryszko', Anna Woźniak², Aneta Sulborska', Agata Konarska', Katarzyna Dąbrowska-Zapart ${ }^{3}$, Kazimiera Chłopek³ ${ }^{3}$, Małgorzata Malkiewicz', Ewa Kalinowska', Małgorzata Puc ${ }^{6,7}$, Agnieszka Lipiec ${ }^{8}$, Beata Żuraw', Daniel Kortych', Dariusz Jurkiewicz' ${ }^{10}$, Kornel Szczygielski ${ }^{10}$, Grzegorz Siergiejk0 ${ }^{11}$, Zenon Siergiejko ${ }^{12}$, Adlam Rapiejko ${ }^{5,13}$, Krystian Tywoniuk ${ }^{14}$, Dorota Myszkowska' ${ }^{15}$, Monika Ziemianin ${ }^{15}$, Barbara Gałusza ${ }^{10}$, Piotr Rapiejko ${ }^{5}, 10$

${ }^{1}$ Department of Botany, University of Life Sciences in Lublin, Poland ${ }^{2}$ Department of General Ophthalmology, Medical University of Lublin, Poland ${ }^{3}$ Department of Paleontology and Stratigraphy, Faculty of Earth Sciences, University of Silesia, Poland

${ }^{4}$ Department of Palaeobotany, Institute of Geological Sciences, University of Wroclaw, Poland

${ }^{5}$ Allergen Research Center, Poland

${ }^{6}$ Department of Botany and Nature Conservation, Faculty of Biology, University of Szczecin, Poland

${ }^{7}$ Molecular Biology and Biotechnology Centre, Faculty of Biology, University of Szczecin, Poland ${ }^{8}$ Department of Prevention of Environmental Hazards and Allergology, Medical University of Warsaw, Poland

${ }^{9}$ Department of Orthopedics and Traumatology, Pomeranian Medical University of Szczecin, Poland ${ }^{10}$ Department of Otolaryngology with Division of Cranio-Maxillo-Facial Surgery in Military Institute of Medicine, Warsaw, Poland ${ }^{11}$ Pediatrics, Gastroenterology and Allergology Department, University Children Hospital, Medical University of Bialystok, Poland

${ }^{12}$ Laboratory of Respiratory Diagnostics and Bronchoscopy, Medical University of Bialystok, Poland ${ }^{13}$ Oxford Archaeology Ltd., Oxford, England

${ }^{14}$ Department of Otolaryngology, Audiology and Phoniatrics, Children's Hospital of Bydgoszcz ${ }^{15}$ Department of Clinical and Environmental Allergology, Jagiellonian University, Medical College

\begin{abstract}
:
The aim of the present study was to compare the mugwort pollen season in 2018 in Bialystok, Bydgoszcz, Cracow, Drawsko-Pomorskie, Lublin, Olsztyn, Opole, Sosnowiec, Szczecin, Warsaw, Wroclaw, and Zielona Gora. Pollen concentration measurements were made by the volumetric method using Burkard or Lanzoni pollen samplers. The pollen season was considered as the period during which $98 \%$ of the total annual pollen count occurred. The Seasonal Pollen Index (SPI) was calculated as the sum of the average daily pollen concentrations throughout the season determined for the individual cities. The mugwort pollen season started earliest in Bialystok (June 21st) and Bydgoszcz (June 25 $5^{\text {th}}$ ), while in the other cities its onset occurred in the first 10 days of July. Significant differences were found in season duration (68-110 days), SPI, and peak value. The longest season occurred in Zielona Gora and Bydgoszcz, while the shortest one in Wroclaw. The highest SPI and maximum concentration values were observed in Lublin and Zielona Gora. In most of the cities, the peak value was recorded in the first 10 days of August. The highest risk of allergy in people sensitive to the pollen of this taxon was found in Zielona Gora, Lublin, and Warsaw.
\end{abstract}

Key words: aeroallergens, pollen count, mugwort (Artemisia), 2018 


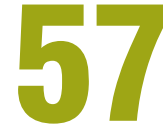
species of the genus Artemisia occur in Europe [1]. The area of their occurrence covers almost all Europe and spreads from the central part of Scandinavia to southern Italy and Spain [2].

14 species of the genus Artemisia are found in Poland and these species bloom from July to the end of September [3]. In 2013 the onset of mugwort pollen shed was recorded already in the middle of June [4]. Most frequently, these are weeds and ruderal plants. Some of them are used for seasoning or medicinal purposes [5]. All mugwort species grow in urban and suburban areas [6].

The common mugwort, Artemisia vulgaris, is most often found both in Poland and in other European countries [2, 5]. Among all European countries, the highest mugwort pollen concentrations are recorded in Poland, Lithuania, Latvia, and Ukraine [2]. Our study shows that in Lublin mugwort pollen accounts for $2.6 \%$ of all pollen grains contained in the aeroplankton [7].

In spite of a relatively low content of atmospheric mugwort pollen, in comparison to the content of pollen of other plant taxa, it ranks third among the most common causes of pollen allergy in Poland, after grass and birch with their pollen content of $9.3 \%$ and $23.6 \%$, respectively $[7,8]$.

The major allergen of Artemisia pollen grains, Art v 1, is homologous to the Ambrosia pollen allergen Amb a 4 . They may cause cross reactivity in sensitive patients [9].

\section{Aim}

The aim of this study was to compare airborne mugwort pollen concentrations in 2018 in Bialystok, Bydgoszcz, Cracow, Drawsko Pomorskie, Lublin, Olsztyn, Opole, Sosnowiec, Szczecin, Warsaw, Wroclaw, and Zielona Gora.

\section{Material and method}

Based on the study results obtained in 2018, an analysis was performed of atmospheric mugwort pollen seasons in 12 cities of Poland. Pollen concentration measurements were made by the volumetric method using Burkard or Lanzoni pollen samplers [10]. The start and end of the Artemisia pollen season were determined. Season duration was determined by the $98 \%$ method. The Seasonal Pollen Index (SPI) was calculated as the sum of the average daily pollen concentrations throughout the season in the individual cities [11]. The peak values and peak dates were compared between all the pollen monitoring sites.

The risk of pollen allergy was determined as the number of days with a concentration exceeding the threshold values, which are $30 \mathrm{P} / \mathrm{m}^{3}, 55 \mathrm{P} / \mathrm{m}^{3}$, and $70 \mathrm{P} /$ $\mathrm{m}^{3}$ for mugwort. At a concentration of $30 \mathrm{P} / \mathrm{m}^{3}$, the first allergy symptoms occur, at $55 \mathrm{P} / \mathrm{m}^{3}$ pollen allergy occurs in all individuals sensitized to mugwort, while at $70 \mathrm{P} / \mathrm{m}^{3}$ allergic people may have severe symptoms [12].

\section{Results and discussion}

In 2018 the mugwort pollen season started in Poland between June $21^{\text {st }}$ and July $13^{\text {th }}$, and in some cities it lasted until the middle of October. The first mugwort pollen grains were observed earliest in Bialystok, while latest in Szczecin (tab. 1).

The pollen season duration was from 68 days (Wroclaw) to 110 days (Bydgoszcz). The period of peak pollen concentrations was recorded in the cities in question between July $28^{\text {th }}$ (Szczecin) and August $10^{\text {th }}$ (Bialystok). The peak value of mugwort pollen concentration ranged between $22 \mathrm{P} / \mathrm{m}^{3}$ (Bydgoszcz) and $88 \mathrm{P} /$ $\mathrm{m}^{3}$ (Lublin) (figs 1-6).

The highest sum of mugwort pollen grains (SPI) in 2018 was recorded in Lublin (1085 grains) and Zielona Gora (1055 grains), whereas in Szczecin, Bialystok, Bydgoszcz, and Cracow the total annual pollen counts were 2.5-3-fold lower (tab. 1).

A high risk of allergy related to a high mugwort pollen concentration (above $55 \mathrm{P} / \mathrm{m}^{3}$ ) occurred in Zielona Gora (4 days), Lublin (3 days), and Warsaw (3 days), while concentrations above $70 \mathrm{P} / \mathrm{m}^{3}$ throughout 1 day were recorded only in Lublin and Zielona Gora (tab. 1).

In most of the cities, the Artemisia pollen seasons were characterized by a condensed pattern, with the occurrence of the highest concentrations in the first half of the season (figs 2, 3, 5, 6), but in Bialystok and Drawsko Pomorskie relatively high peaks occurred also in the second half of the season, which may be evidence of a significant proportion of pollen of several species of the genus Artemisia (figs 1, 4).

In Lublin the SPI value for Artemisia was much lower in 2018 than in previous years in this city, e.g. during the period 2001-2005 when it reached 15502533 [13], and this value was also lower than the average for 2001-2012 when it stood at 1741 [14]. In 2015 , on the other hand, the value of the above-mentioned parameter was similar to that determined in 2018 [15]. 
Table 1. Characteristics of mugwort pollen season in 2018.

\begin{tabular}{|c|c|c|c|c|c|c|c|c|c|c|c|c|}
\hline $\begin{array}{l}\text { Features of } \\
\text { pollen season }\end{array}$ & Bialystok & $\begin{array}{c}\text { Byd- } \\
\text { goszez }\end{array}$ & Cracow & \begin{tabular}{|l|} 
Drawsko \\
Pomorskie
\end{tabular} & Lublin & Olsztyn & Opole & $\begin{array}{l}\text { Sosno- } \\
\text { wiec }\end{array}$ & Szczecin & Warsaw & Wroclaw & $\begin{array}{l}\text { Zielona } \\
\text { Gora }\end{array}$ \\
\hline $\begin{array}{l}\text { Duration of } \\
\text { pollen season } \\
\text { (number of } \\
\text { days) }\end{array}$ & $\begin{array}{c}21.06- \\
10.09 \\
(82)\end{array}$ & $\begin{array}{c}25.06- \\
12.10 \\
(110)\end{array}$ & $\begin{array}{c}5.07- \\
15.09 \\
(73)\end{array}$ & $\begin{array}{c}3.07-13.10 \\
(103)\end{array}$ & $\begin{array}{c}8.07- \\
23.09 \\
(78)\end{array}$ & $\begin{array}{c}8.07- \\
4.10 \\
(89)\end{array}$ & $\begin{array}{l}5.07- \\
4.10 \\
(92)\end{array}$ & $\begin{array}{l}3.07- \\
1.10 \\
(91)\end{array}$ & $\begin{array}{c}13.07- \\
1.10 \\
(81)\end{array}$ & $\begin{array}{l}8.07- \\
13.10 \\
(98)\end{array}$ & $\begin{array}{c}3.07- \\
8.09 \\
(68)\end{array}$ & $\begin{array}{l}1.07- \\
15.10 \\
(107)\end{array}$ \\
\hline $\begin{array}{l}\text { Seasonal } \\
\text { Pollen Index } \\
98 \%\end{array}$ & 349 & 440 & 423 & 861 & 1085 & 692 & 615 & 397 & 296 & 957 & 733 & 1055 \\
\hline $\begin{array}{l}\text { Peak value } \\
\text { and peak date }\end{array}$ & $\begin{array}{c}30 \\
(10.08)\end{array}$ & $\begin{array}{c}22 \\
(3.08)\end{array}$ & $\begin{array}{c}41 \\
(4.08)\end{array}$ & $\begin{array}{c}67 \\
(1.08)\end{array}$ & $\begin{array}{c}88 \\
(3.08)\end{array}$ & $\begin{array}{c}67 \\
(5.08)\end{array}$ & $\begin{array}{c}53 \\
(8.08)\end{array}$ & $\begin{array}{c}36 \\
(3.08)\end{array}$ & $\begin{array}{c}32 \\
(28.07)\end{array}$ & $\begin{array}{c}68 \\
(7.08)\end{array}$ & $\begin{array}{c}65 \\
(8.08)\end{array}$ & $\begin{array}{c}74 \\
(4.08)\end{array}$ \\
\hline $\begin{array}{l}\text { Days } \geq 30 \mathrm{P} / \\
\mathrm{m}^{3}{ }^{*}[12]\end{array}$ & 1 & 0 & 2 & 7 & 14 & 7 & 5 & 2 & 1 & 11 & 8 & 12 \\
\hline $\begin{array}{l}\text { Days } \geq 55 \mathrm{P} / \\
\mathrm{m}^{3 * *}[12]\end{array}$ & 0 & 0 & 0 & 1 & 3 & 2 & 0 & 0 & 0 & 3 & 2 & 4 \\
\hline $\begin{array}{l}\text { Days } \geq 70 \mathrm{P} / \\
\mathrm{m}^{3 * * \star}[12]\end{array}$ & 0 & 0 & 0 & 0 & 1 & 0 & 0 & 0 & 0 & 0 & 0 & 1 \\
\hline
\end{tabular}

${ }^{\star}$ First allergy symptoms.

** Allergic reactions in most patients.

*** Trigger acute clinical symptoms.

Figure 1. Mugwort pollen count in Bialystok and Bydgoszcz in 2018.

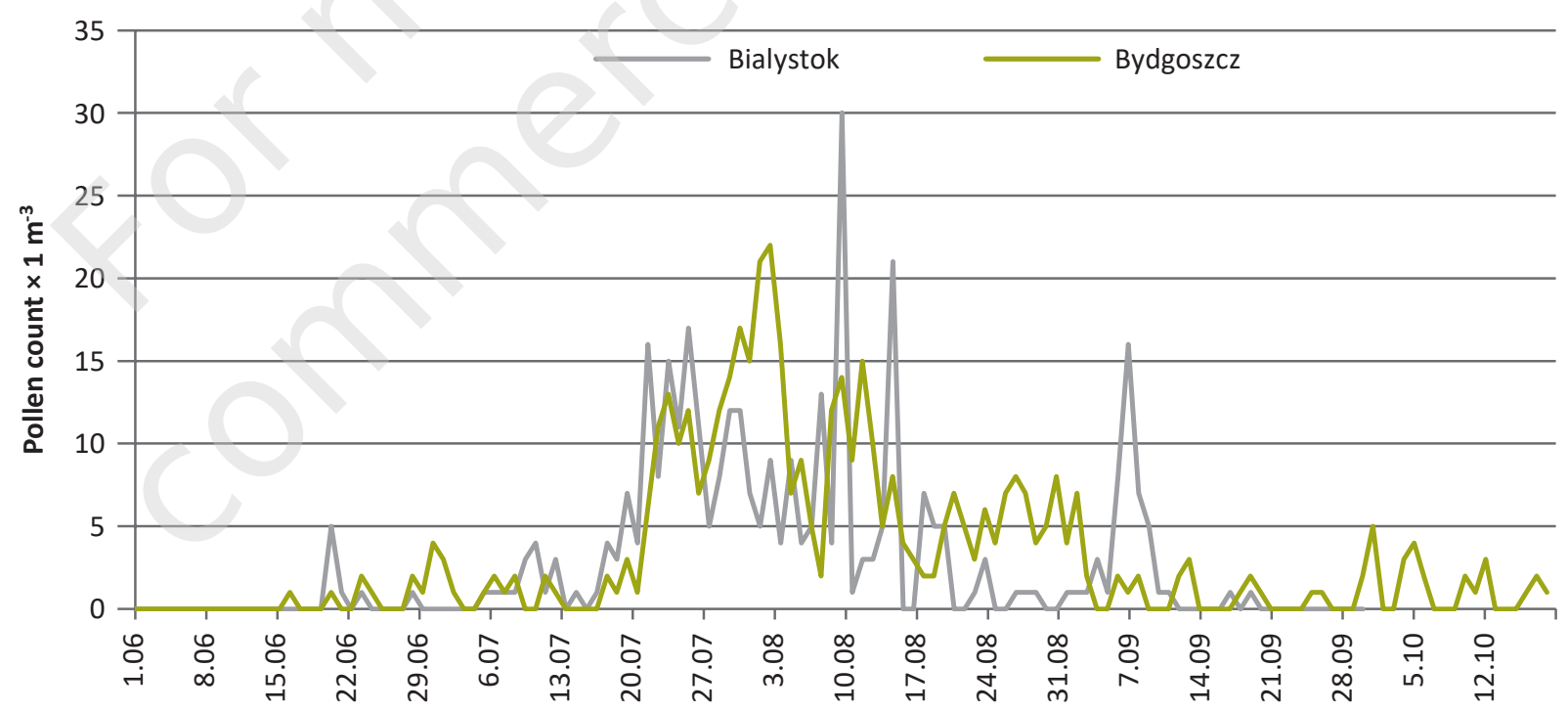

Figure 2. Mugwort pollen count in Sosnowiec and Wroclaw in 2018.

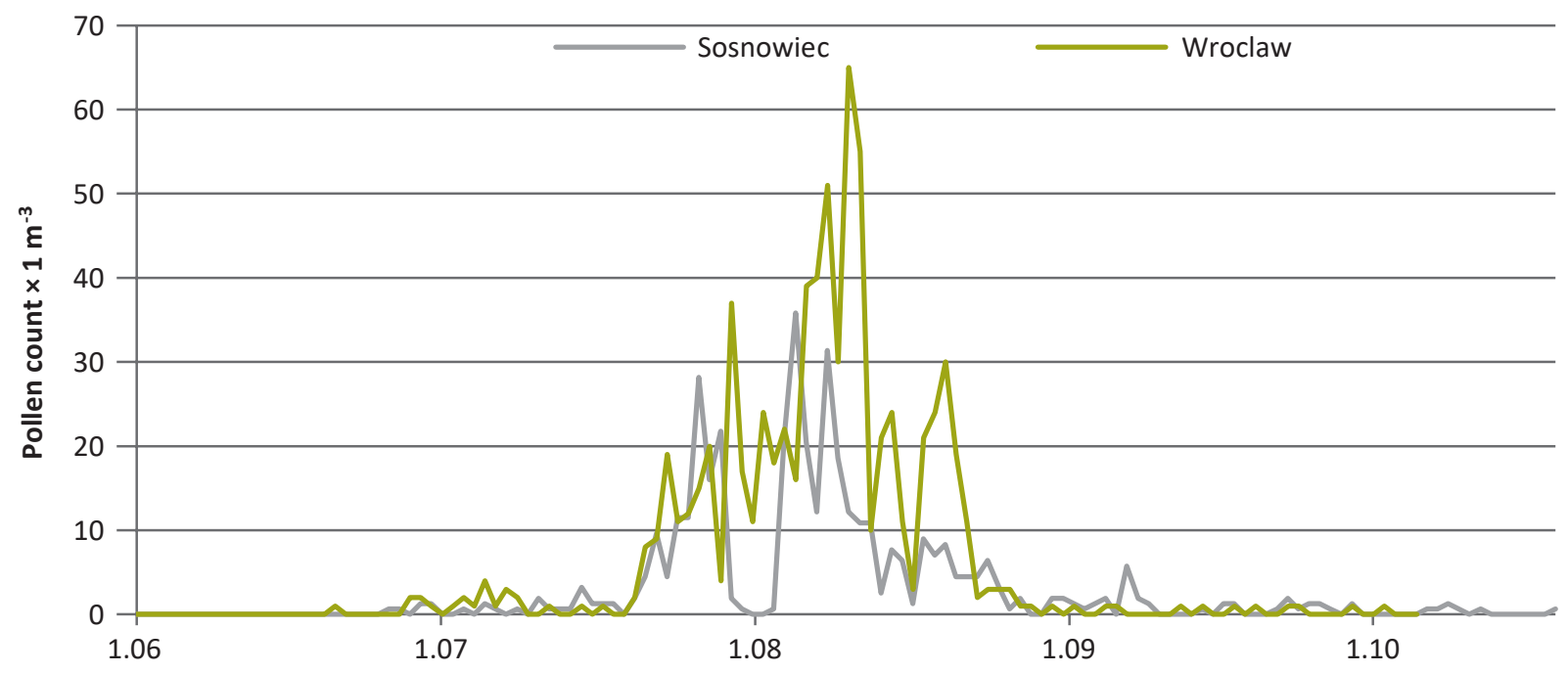


Figure 3. Mugwort pollen count in Cracow and Lublin in 2018.

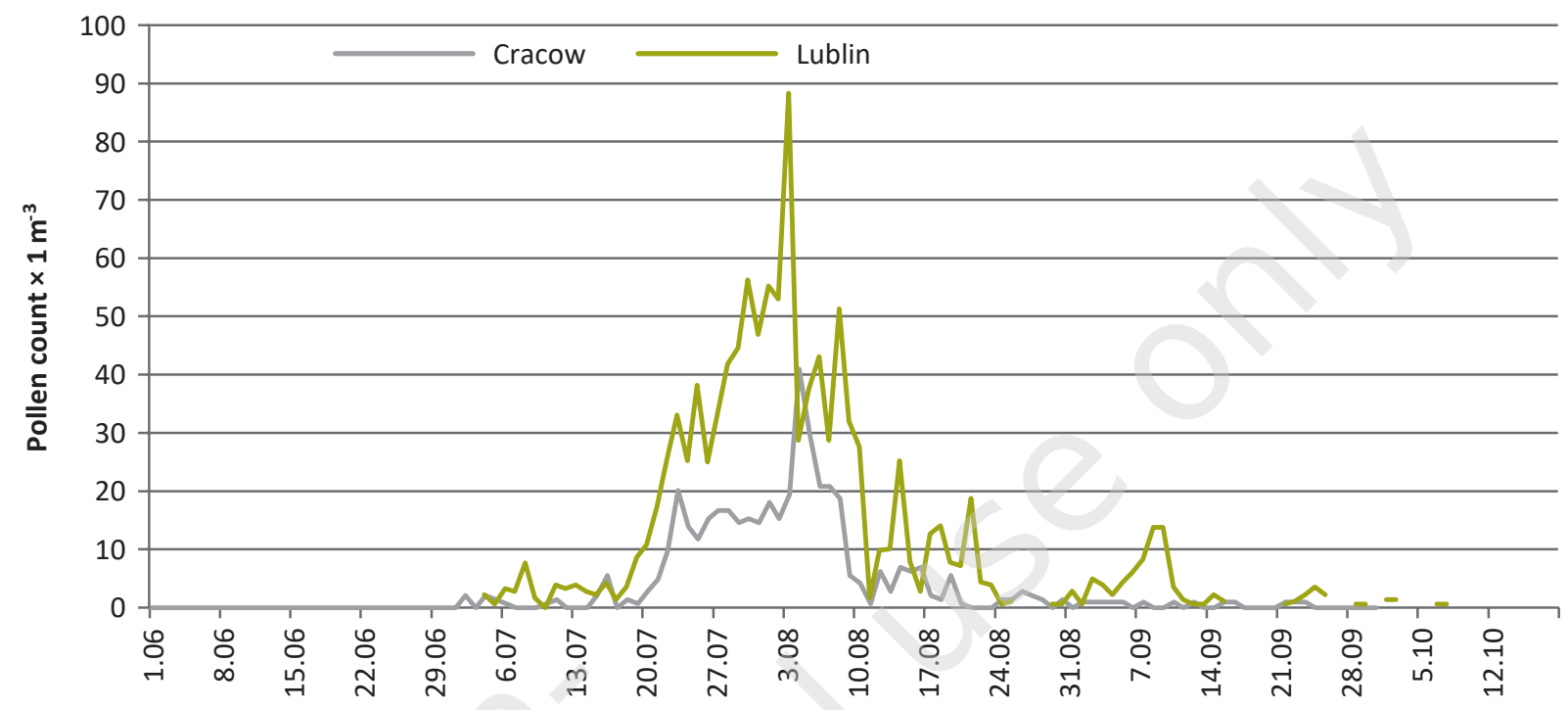

Figure 4. Mugwort pollen count in Drawsko Pomorskie and Szczecin in 2018.

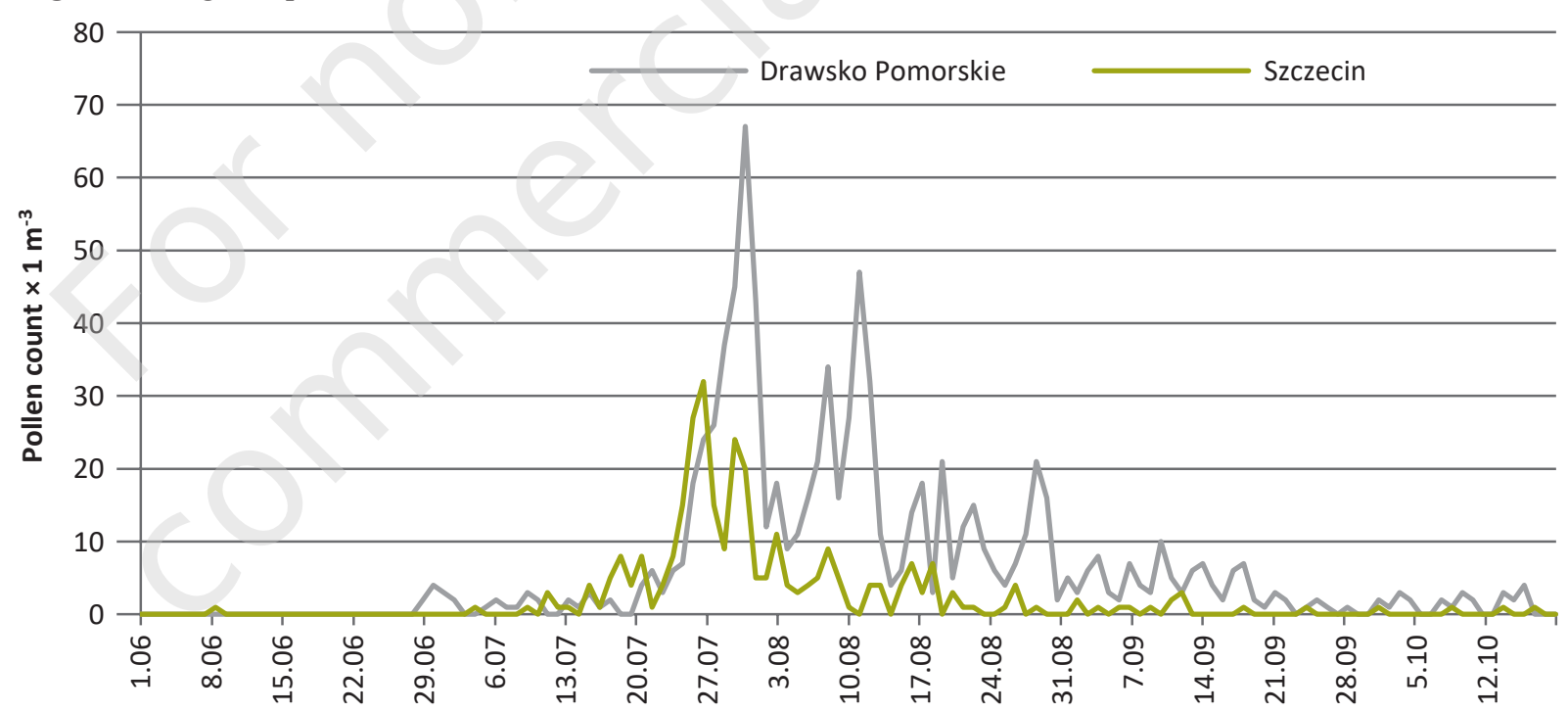

Figure 5. Mugwort pollen count in Zielona Gora and Warsaw in 2018.

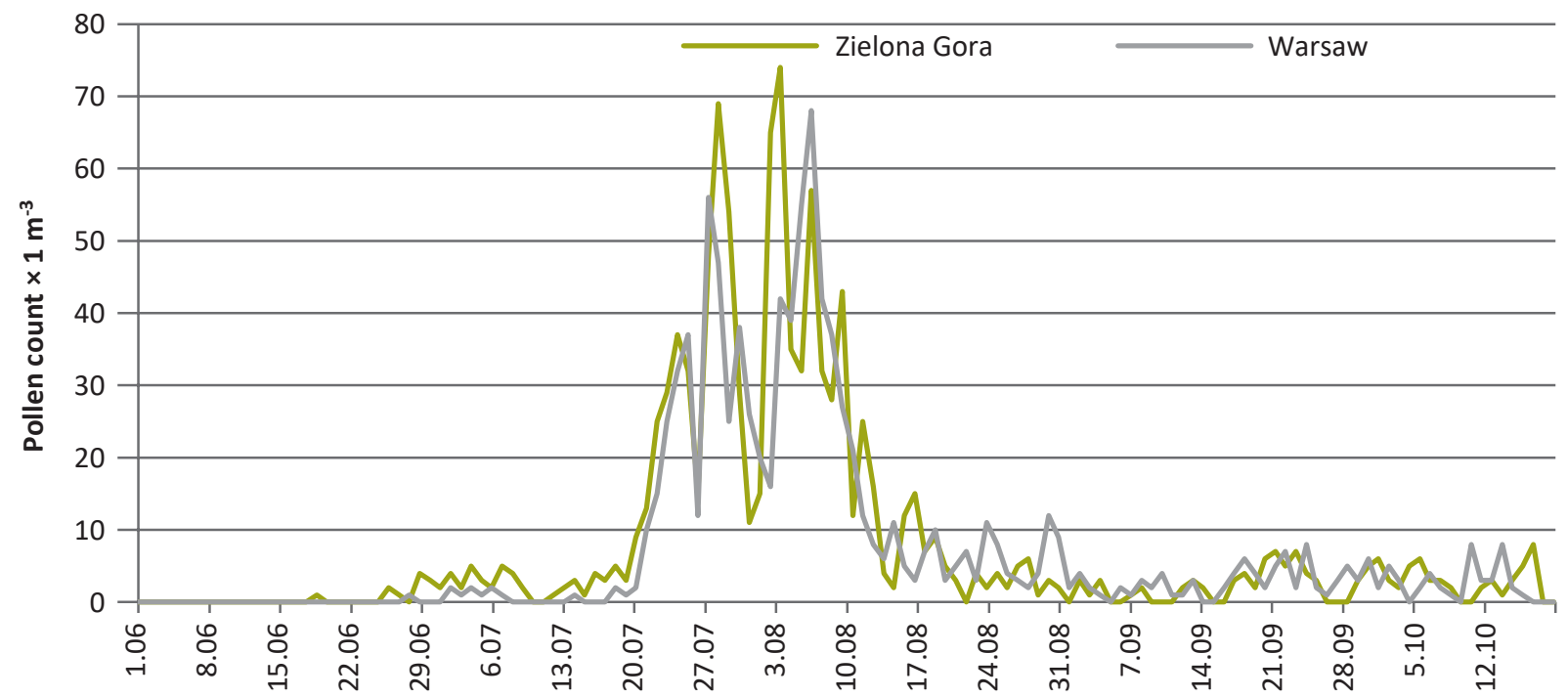


Figure 6. Mugwort pollen count in Olsztyn and Opole in 2018.

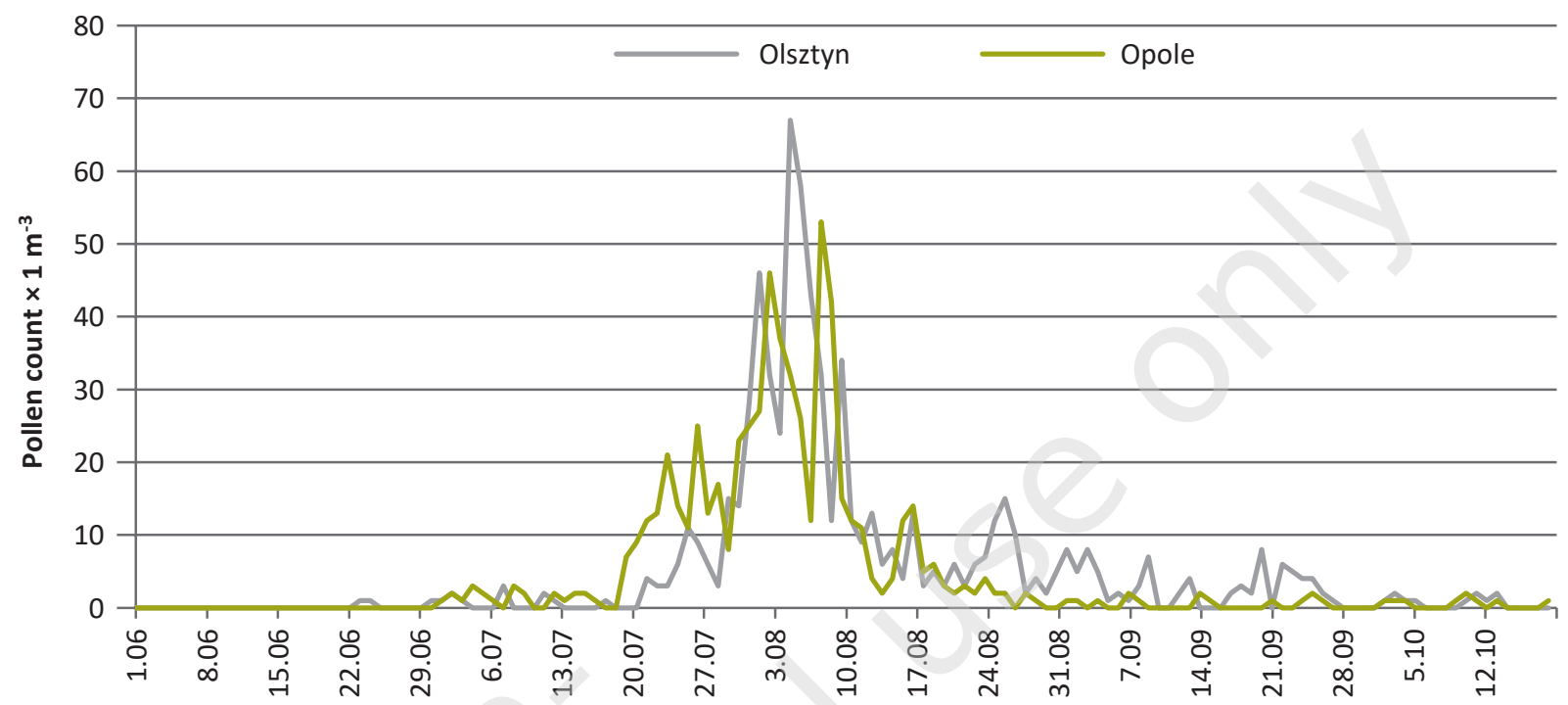

\section{Conclusions}

1. The mugwort pollen season in 2018 in the studied cities lasted from the third 10 days of June until the middle of October, and the longest season (Bydgoszcz) reached 110 days.

2. The highest daily mugwort pollen concentration was found in Lublin $\left(88 \mathrm{P} / \mathrm{m}^{3}\right)$. At most of the pollen monitoring sites, peak pollen shed occurred in the first 10 days of August.

3. The highest risk of pollen allergy during the mugwort pollen season was shown in Zielona Gora, Lublin, and Warsaw.

\section{References}

1. Tutin TG. Artemisia L. In: Tutin TG, Burges NA, Chater AO et al (eds). Flora Europea: Plantaginaceae to Compositae (and Rubiaceae), vol. 4. Cambridge, Cambridge University Press 1976.

2. Skjøth CA, Šikoparija B, Jäger S, and EAN-Network. Pollen sources. In: Sofiev M, Bergmann K-Ch (eds). Allergenic Pollen. Springer, Dordrecht, Heidelberg, New York, London 2013.

3. Rutkowski L. Klucz do oznaczania roślin naczyniowych Polski niżowej. Warszawa, Państwowe Wydawnictwo Naukowe 2004.

4. Puc M, Kruczek A, Lipiec A et al. Pylek bylicy w powietrzu wybranych miast Polski w 2013 roku. Alergoprofil 2013, 9(3): 29-33.

5. Rapiejko P. Alergeny pytku roślin. Medical Education, Warszawa 2012.

6. D'Amato G, Cecchi L, Bonini $S$ et al. Allergenic pollen and pollen allergy in Europe. Allergy 2007, 62: 976-990.
7. Piotrowska-Weryszko K, Weryszko-Chmielewska E. The airborne pollen calendar for Lublin, central-eastern Poland. Ann Agric Environ Med 2014, 21(3): 541-545.

8. Rapiejko P, Weryszko-Chmielewska E. Pytek bylicy. Alerg Astma Immunol 1999, 43(3): 139-142.

9. Wopfner N, Gadermaier G, Egger $M$ et al. The spectrum of allergens in ragweed and mugwort pollen. Int Arch Allergy Appl Immunol 2005, 138: 337-346.

10. Mandrioli P, Camtois P, Domingez E et al. Sampling: Principles and Techniques. In: Mandrioli P, Comtois P, Levizzani V (eds). Methods in Aerobiology. Pitagora Editrice Bologna, Bologna 1998

11. Comtois P. Statistical analysis of aerobiological data. In: Mandrioli P, Comtois P, Levizzani V (eds). Methods in Aerobiology. Pitagora Editrice Bologna, Bologna 1998.

12. Rapiejko P, Stankiewicz W, Szczygielski K et al. Progowe stężenia pytku roślin niezbędne do wywołania objawów alergicznych. Otolaryngol Pol 2007, 61(4): 591-594.

13. Weryszko-Chmielewska E, Piotrowska K. Pyłek wybranych taksonów roślin w powietrzu Lublina w latach 2001-2005. In: Weryszko-Chmielewska E (ed). Pyłek roślin w aeroplanktonie różnych regionów Polski. Wyd. Akademii Medycznej, Lublin 2006.

14. Weryszko-Chmielewska E, Piotrowska-Weryszko K. Charakterystyka sezonów pytkowych wybranych taksonów roślin w Lublinie w latach 2001-2013. In: Weryszko-Chmielewska E (ed). Ziarna pyłku i zarodniki grzybów w powietrzu różnych regionów Polski. Wyd. Norbertinum, Lublin 2014.

15. Piotrowska-Weryszko K, Weryszko-Chmielewska E, Rapiejko $P$ et al. Mugwort pollen season in southern Poland and Lviv (Ukraine) in 2015. Alergoprofil 2016, 22(1): 26-30. 
ORCID

E. Weryszko-Chmielewska - ID - orcid.org/0000-0001-8410-2757 K. Piotrowska-Weryszko - ID - orcid.org/ 0000-0003-3827-3218 A. Woźniak - ID - orcid.org/0000-0003-0865-6541 A. Sulborska - ID-orcid.org/0000-0002-7720-0719 A. Konarska - ID-orcid.org/ 0000-0003-2174-7608 K. Dabrowska-Zapart - ID - orcid.org/ 0000-0002-8976-7739 E. Kalinowska - ID - orcid.org/ 0000-0003-4821-6882 M. Puc - ID - orcid.org/0000-0001-6734-9352 A. Lipiec - ID - orcid.org/0000-0003-3037-232 K. Szczygielski - ID - orcid.org/ 0000-0002-3717-5424 K. Tywoniuk - ID - orcid.org/0000-0002-4610-0002

D. Myszkowska - ID - orcid.org/ 0000-0002-1493-3990

M. Ziemianin - ID - orcid.org/ 0000-0003-4568-8710

B. Gałusza - ID - orcid org/ 0000-0002-9594-5108

P. Rapiejko - ID - orcid.org/ 0000-0003-3868-0294
Author's contributions: Weryszko-Chmielewska E: 15\%; Piotrowska-Weryszko K: 7.5\%; Sulborska A: 7.5\%; other Authors: 3.3\% each.

Conflict of interests: The authors declare that they have no competing interests.

Financial support: Does not occur.

Ethics: The contents presented in this paper are compatible with the rules the Declaration of Helsinki, EU directives and standardized requirements for medical journals.

Research in Bialystok, Bydgoszcz, Drawsko Pomorskie, Olsztyn, Opole, Piotrkow Trybunalski, Warsaw and Zielona Gora funded by Allergen Research Center Ltd.

Corresponding author:

Prof. Elżbieta Weryszko-Chmielewska, MD, PhD

Department of Botany,

University of Life Sciences in Lublin

20-950 Lublin, Akademicka 15

e-mail: elaweryszko@wp.pl 